\title{
RAPID INTUBATION WITH FAZADINIUM AND SUXAMETHONIUM
}

\author{
S. Mehta ${ }^{*}$, K. LeWiN ${ }^{*}$, AND K. FidLer ${ }^{\dagger}$
}

CONSIDERABLE RESEARCH has been directed towards developing a non-depolarizing neuromuscular blocking agent which will rapidly produce profound muscular relaxation of short duration, similar to suxamethonium. At present, suxamethonium, a depolarizing drug, is the only muscle relaxant available which provides optimum conditions for intubation during emergency situations. However, the abdominal muscle fasciculation caused by suxamethonium can increase intra-abdominal and intragastric pressure to the extent that gastric contents are forced into the oesophagus and the pharynx., ${ }^{1,2}$ The onset of action of the traditionally used non-depolarizing muscle relaxants is too slow and may take at least 120 seconds before it is possible to perform intubation. ${ }^{3}$ This makes them unsuitable for intubation in patients with a full stomach. Under these circumstances the tracheobronchial tree of the patient is unprotected and aspiration of gastric contents is one of the commonest accidents that can occur at that time. Aspiration of vomitus or regurgitated material at induction of anaesthesia but before intubation, particularly in emergency situations, is among the most common causes of death in anaesthesia. ${ }^{4} \mathrm{Ob}-$ viously this delay between the onset of induction of anaesthesia and intubation can be reduced and the danger of aspiration minimized if a non-depolarizing type of relaxant can provide rapid induction of relaxation. Suxamethonium has other undesirable side-effects which include muscle pains, ${ }^{5}$ prolonged apnoea, production of hyperkalaemia and onset of dysrhythmias.

Fazadinium (AH 8165D; Fazadon ${ }^{\circledR}$ ) is a new non-depolarizing muscle relaxant, the clinical use of which has been described by Simpson, et al. and Arora, et al. ${ }^{6,7}$ The purpose of the present study has been to determine how quickly intubation can be performed using fazadinium and to make a comparison with the effect of suxamethonium under similar conditions.

\section{MethoD}

Adult patients were randomly allocated to one of five groups according to the relaxant and dose to be given. All had normal cardiovascular and respiratory systems. They were to undergo a variety of surgical procedures for which tracheal intubation was required. No patient in whom there was any anatomical difficulty with laryngoscopy or intubation was included in the study.

All patients received premedication consisting of atropine $0.6 \mathrm{mg}$ and meperidine

Correspondence to: Dr. S. Mehta, Consultant Anaesthetist, General Hospital, Burnley, Lancs., England, BB10 2PQ.

Department of Anaesthesia, General Hospital, Burnley, Lancs., England.

†Clinical Division, Glaxo Research Ltd, Greenford, Mddsx, England.

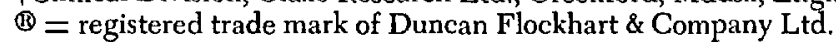


$75 \mathrm{mg}$ administered intramuscularly 45 to 60 minutes before induction of anaesthesia. They were preoxygenated with 100 per cent oxygen for five minutes so that the exact time of attaining optimal intubating conditions could be determined without the need to inflate the lungs with oxygen after the relaxant had been given. Induction of anaesthesia was with thiopentone $4 \mathrm{mg} / \mathrm{kg}$ given into a large vein in the antecubital fossa over a period of 15 seconds, followed by the relaxant. A stopwatch was started when the injection of the relaxant was completed. The mean times from end of injection to end of intubation were recorded for each relaxant. The intubating conditions were graded according to the scheme described by Lund and Stovner. ${ }^{8}$

Grade 3 - Excellent: Well separated cords, not moving, no bucking on the tube.

Grade 2 - Satisfactory: Slight movement of the cords when touched, only slight bucking for a short period after intubation.

Grade 1 - Fair: Conditions less favourable than in the previous category but permitting intubation.

\section{RESULTS}

Details of the patients and doses of relaxants given to each of the five groups are shown in Table I. Two doses of fazadinium ( $1.0 \mathrm{mg} / \mathrm{kg}$ and $1.5 \mathrm{mg} / \mathrm{kg}$ ) were given on a weight basis and compared with three standard doses of suxamethonium $(50 \mathrm{mg}, 75 \mathrm{mg}$ and $100 \mathrm{mg}$ ). The duration of action of the higher dose of fazadinium was found to be too long for the type of operation and this group was therefore abandoned after seven patients. The intubation times and characteristics of these seven were retained for comparison in the statistical analysis.

Table II shows the distribution of intubating conditions within cach of the five groups. There were no statistically significant differences between the two doses of fazadinium $(p>0.5)$, between the two lower doses of suxamethonium $(p>0.5)$ or between the two lowest doses of suxamethonium and either of the doses of fazadinium $(p>0.5)$. However, the results after suxamethonium $100 \mathrm{mg}$ were highly significantly different from the results after both doses of fazadinium (chisquare $=4.19 ; \mathrm{p}<0.001$ ) and after the other two doses of suxamethonium (chisquare $=3.98 ; \mathrm{p}<0.001)$.

The mean times from the end of injection to the end of intubation are shown in Table III. There was no significant difference between the results for the two different doses of fazadinium which could therefore be added together. The mean

TABLE I

Details of Patients and dose of Relaxant given TO THE FIVE GROUPS

\begin{tabular}{lcccccc}
\hline $\begin{array}{c}\text { Dose of muscle } \\
\text { relaxant }\end{array}$ & $\begin{array}{c}\text { No. of } \\
\text { patients }\end{array}$ & F & Sex & M & $\begin{array}{c}\text { Age in years } \\
\text { (range) }\end{array}$ & $\begin{array}{c}\text { Weight in kg } \\
\text { (range) }\end{array}$ \\
\hline Fazadinium 1 $\mathrm{mg} / \mathrm{kg}$ & 24 & 10 & 14 & $58(21-75)$ & $59(44-83)$ \\
Fazadinium $1.5 \mathrm{mg} / \mathrm{kg}$ & 7 & 3 & 4 & $52(33-78)$ & $66(52-85)$ \\
Suxamethonium $50 \mathrm{mg}$ & 25 & 17 & 8 & $46(16-78)$ & $63(41-84)$ \\
Suxamethonium $75 \mathrm{mg}$ & 25 & 18 & 7 & $47(23-80)$ & $63(43-90)$ \\
Suxamethonium $100 \mathrm{mg}$ & 25 & 20 & 4 & $45(20-73)$ & $66(49-80)$ \\
\hline
\end{tabular}


TABLE II

InTUBATING Conditions FOLlowing THE DIFFERENT DOSES OF FAZADINIUM AND SUXAMETHONIUM GRADED ACCORDING TO THE SCHEME OF LUND AND StovNer (1962) Number of PATIENTS IN EACH GRADE

\begin{tabular}{lrrr}
\hline \hline & \multicolumn{3}{c}{ Grade of Intubation } \\
\cline { 2 - 4 } Dose of relaxant & 1 & 2 & 3 \\
\hline Fazadinium $1 \mathrm{mg} / \mathrm{kg}$ & 12 & 10 & 2 \\
Fazadinium $1.5 \mathrm{mg} / \mathrm{kg}$ & 3 & 4 & -3 \\
Suxamethonium $50 \mathrm{mg}$ & 12 & 10 & 4 \\
Suxamethonium $75 \mathrm{mg}$ & 11 & 10 & 13 \\
Suxamethonium $100 \mathrm{mg}$ & 2 & 10 & \\
\hline
\end{tabular}

TABLE III

MEAN TIME FROM THE END OF INJECTION TO THE END OF INTUBATION IN THE FIVE GROUPS OF PATIENTS

\begin{tabular}{lc}
\hline Dose of relaxant & $\begin{array}{c}\text { Mean time from end } \\
\text { of injection to end of } \\
\text { intubation (seconds) } \pm \mathrm{SE}\end{array}$ \\
\hline Fazadinium $1 \mathrm{mg} / \mathrm{kg}$ & $27 \pm 2$ \\
Fazadinium $1.5 \mathrm{mg} / \mathrm{kg}$ & $26 \pm 3$ \\
Suxamethonium $50 \mathrm{mg}$ & $31 \pm 2$ \\
Suxamethonjum $75 \mathrm{mg}$ & $28 \pm 0.8$ \\
Suxamethonium $100 \mathrm{mg}$ & $21 \pm 0.8$ \\
\hline
\end{tabular}

for both doses ( 31 patients) was 26.9. The mean time to intubation for suxamethonium $100 \mathrm{mg}$ was significantly different from suxamethonium $50 \mathrm{mg}$ or $75 \mathrm{mg}$ groups and from both doses of fazadinium $(p<0.02)$. The results with fazadinium were not significantly different from the suxamethonium $50 \mathrm{mg}$ group $(\mathrm{p}>0.1)$ or the suxamethonium $75 \mathrm{mg}$ group $(\mathrm{p}>0.5$ ).

\section{Discussion}

Studies of the intubation characteristics of different muscle relaxants tend to be subjective due, primarily, to the anaesthetist's skill and also because of the physicopharmacological properties of the compounds involved. Ideally such investigations should be designed on a double-blind basis but in this study the distinctive colour of the fazadinium solution and the fasciculations following suxamethonium made their identities obvious.

Arora, et al. ${ }^{7}$ after their initial clinical experience with fazadinium reported that satisfactory intubating conditions can be obtained after $1 \mathrm{mg} / \mathrm{kg}$ of this drug. However, they only attempted intubation at 60 to 120 seconds after the injection of fazadinium.

Young, et al.,${ }^{9}$ in a recent investigation compared intubating conditions at 30,45 and 75 seconds after the administration of fazadinium $1.25 \mathrm{mg} / \mathrm{kg}$ and suxamethonium $1 \mathrm{mg} / \mathrm{kg}$. They found that the incidence of excellent overall intubating conditions was significantly higher with suxamethonium at all of these times.

The results presented in this study indicate that using lower doses of suxa- 
methonium ( 50 and $75 \mathrm{mg}$ ) there are no significant differences between the intubation times obtained when suxamethonium or fazadinium are given. This is in contrast to the findings of Young, et al. ${ }^{9}$ as the average dose of suxamethonium administered to each patient in our $75 \mathrm{mg}$ dose group was greater than $1 \mathrm{mg} / \mathrm{kg}$. Suxamethonium $100 \mathrm{mg}$ gave the shortest time interval between the end of injection and intubation. Thus the rapid onset of action of suxamethonium seems to be dose related. This could not be established for fazadinium due to the prolonged duration of action seen with the higher dose of $1.5 \mathrm{mg} / \mathrm{kg}$. The highest dose of suxamethonium used in this study also produced a significantly greater number of patients with excellent intubating conditions than either fazadinium or suxamethonium at lower doses.

In clinical anaesthesia where there is a risk of regurgitation during induction, as may be the case in emergency obstetric procedures, operations for the relief of intestinal obstruction or other operations in unprepared patients, rapid intubation is essential. In these circumstances suxamethonium $100 \mathrm{mg}$ (approximately 1.5 $\mathrm{mg} / \mathrm{kg}$ body weight) provides better intubating conditions but with all the undesirable side effects associated with its depolarizing action on the motor end plate and its post-ganglionic parasympathomimetic actions.

\section{SuMMARY}

Fazadinium at two dose levels $(1 \mathrm{mg} / \mathrm{kg}$ and $1.5 \mathrm{mg} / \mathrm{kg}$ ) and suxamethonium at three dose levels $(50 \mathrm{mg}, 75 \mathrm{mg}$ and $100 \mathrm{mg}$ ) were investigated in 106 adult patients to determine the time interval from injection to tracheal intubation. The intubating conditions were graded according to the scheme described by Lund and Stovner. Suxamethonium $100 \mathrm{mg}$ gave the shortest time interval between the end of injection and intubation. There was no significant difference between the intubation time when smaller doses of suxamethonium (50 $\mathrm{mg}$ and $75 \mathrm{mg}$ ) were used and those when AH8165 ( $1 \mathrm{mg}$ and $1.5 \mathrm{mg} / \mathrm{kg}$ ) were given. Suxamethonium $100 \mathrm{mg}$ also produced a significantly higher incidence of excellent intubating conditions. The clinical implications of the findings are discussed.

\section{RÉSUMÉ}

Cette étude portait sur le suxamethonium et le fazadinium, un nouveau relaxant non dépolarisant, et avait pour but de comparer le délai séparant linjection et l'intubation. La qualité de relâchement obtenue a également été évaluée suivant le barème de Lund et Stovner.

Cent six patients adultes ont fait l'objet de nos observations. Les doses utilisées étaient de 1 et de $1.5 \mathrm{mg} /$ kilo pour le Fazadinium et de 50,75 et $100 \mathrm{mg}$ pour le suxamenthonium.

Le suxamethonium, à la dose de $100 \mathrm{mg}$, a domné les plus cours délais entre la fin de l'injection et l'intubation.

Les intervalles n'étaient pas significativement différents entre le fazadinium à $1.5 \mathrm{mg} / \mathrm{kilo}$ et le suzamethonium lorsqu'il était utilisé à des doses de 50 ou de $75 \mathrm{mg}$. 
Une dose de $100 \mathrm{mg}$ de suxamethonium produisait également et de façon significative un plus haut pourcentage de conditions excellentes pour l'intubation. Les auteurs commentment les applications cliniques de leurs résultats.

\section{ACKNOWLEDGMENTS}

The authors would like to acknowledge the kind help and co-operation of the operating theatre staff and technicians of Hartley Hospital, Colne. We also thank Mr. A.J. Davey FIS of Research Services Division, Allen \& Hanburys Research Ltd. for statistical advice and Mrs. M. Lambert and Miss S. Reed for secretarial help.

\section{REFERENCES}

1. Andersen, N. Changes in intragastric pressure following the administration of suxamethonium. British Journal of Anaesthesia 34:363 (1962).

2. Roe, R.B. The effect of suxamethonium on intragastric pressure. Anaesthesia 17: 179 (1962).

3. Harrison, G.A. The cardiovascular effects and some relaxant properties of four relaxants in patients about to undergo cardiac surgery. British Joumal of Anaesthesia 44: 485 (1972).

4. Dinvick, O.P. Deaths associated with anaesthesia: Observations on 600 cases. Anaesthesia 19:536 (1964).

5. Churchill-Davidson, H.C. Suxamethonium (succinylcholine chloride) and muscle pains. British Medical Journal 1: 74 (1954).

6. Simpson, B.R., Savege, T.M., Foley, E.I., Ross, L.A., Strunin, L., Walton, B., Maxwell, M.P., \& Harnis, D.M. An azobis-arylimidazo-pyridinium derivative: A rapidly acting non-depolarizing muscle relaxant. Lancet 1 : 516 (1972).

7. Arora M.V., Clarke, R.S.J., Dundee, J.W., \& MoOre, J. Initial clinical experience with AH8165D, a new rapidly acting nondepolarizing muscle relaxant. Anaesthesia 28:188 (1973).

8. LUND, I. \& Stovner, J. Dose response curves for tubocurarine, alcuronium and pancuronium. Acta anaesthesiologica scandinavica, Suppl. 37: 238 (1970).

9. Younc, H.S.A., Clakke, R.S.J., \& DundeE, J.W. Intubating conditions with AH8165 and suxamethonium. Anaesthesia 30: 30 (1975). 